\title{
Non-Realist Cognitivism, Truthmaking, and Ontological Cheating
}

\author{
Farbod Akhlaghi \\ University of Oxford ${ }^{1}$ \\ Forthcoming in Ethics
}

\begin{abstract}
Derek Parfit defended Non-Realist Cognitivism. It is an open secret that this meta-ethical theory is often thought at best puzzling and at worst objectionably unclear. Employing truthmaker theory, I provide an account of Non-Realist Cognitivism that dispels charges of objectionable unclarity, clarifies how to assess it, and explains why, if plausible, it would be an attractive theory. I develop concerns that the theory involves cheating into an objection that ultimately reveals Non-Realist Cognitivism faces a dilemma. Whether it can escape demands further attention. In bridging meta-ethics and the truthmaking literature, I illustrate the importance of greater metametaphysical reflection in meta-ethics.
\end{abstract}

\section{Introduction}

Meta-ethicists are much concerned with Derek Parfit's objections to meta-ethical theories other than his own. It is an open secret, however, that they remain perplexed by Parfit's positive view he called Non-Realist Cognitivism (NRC).

NRC endorses a range of traditional non-naturalist realist commitments about the metaphysics of normativity. But it adds that true irreducibly normative claims are not 'made to be true by correctly describing, or corresponding to, how things are in some part of reality', that

\footnotetext{
${ }^{1}$ Comments very welcome to farbod.akhlaghi-ghaffarokh@philosophy.ox.ac.uk or farbod.akhlaghi.g@gmail.com.
} 
is, their truth has 'no ontological implications'. ${ }^{2}$ Normative facts and properties, NRC maintains, exist only in a 'non-ontological' sense of 'exist'. They do not face any 'difficult ontological questions' and avoid ontological objections altogether. ${ }^{3}$

NRC is typically only mentioned through quotations from Parfit, sometimes partially unpacked only to be rejected as objectionably unclear, or less commonly directly engaged with (though never sympathetically). ${ }^{4}$ There is an explanation for this. First, Parfit's claims above are notoriously difficult to plausibly interpret. ${ }^{5}$ Second, such interpretive difficulty generates further unclarity regarding how to assess NRC.

Underlying these concerns about NRC's intelligibility and plausibility is a thought that I suspect is often had but rarely expressed: NRC seems like cheating. For positing a 'non-ontological' sense of existence for normative phenomena looks ad-hoc, made solely to insulate NRC's nonnaturalist realist commitments from what some believe are decisive ontological objections.

In this paper, I have three related aims. First, to provide an account of NRC that eliminates common charges of objectionable unclarity and illuminates the hitherto opaque

\footnotetext{
${ }^{2}$ Derek Parfit, On What Matters: Volume Three (Oxford: Oxford University Press, 2017), 58-59; Derek Parfit, On What Matters: Volume Two (Oxford: Oxford University Press, 2011b), 486

${ }^{3}$ Parfit, On What Matters: Volume Three, 62

${ }^{4}$ For examples of the first and second see David Enoch, Taking Morality Seriously: A Defense of Robust Realism (Oxford: Oxford University Press, 2011), §5.3; Terrence Cuneo and Russ Shafer-Landau, “The Moral Fixed Points: New Directions for Moral Nonnaturalism," Philosophical Studies 171 (2014): 399-443; Christopher Cowie, “A New Explanatory Challenge for Non-Naturalists," Res Philosophica 91 (2014): 661-676; Georg Gasser, "Normative Objectivity Without Ontological Commitment?," Topoi 37 (2018): 561-570; Krister Bykvist and Jonas Olson, "What Matters in Metaethics," Analysis 79 (2019): 341-349. For the third, see Jussi Suikkanen, "Non-Realist Cognitivism, Truth, and Objectivity," Acta Analytica 32 (2017): 193-212; Kian Mintz-Woo, “On Parfit's Ontology,", Canadian Journal of Philosophy 48 (2018): 707-725; Herman Veluwenkamp, "Parfit and Scanlon's Non-Metaphysical Moral Realism as Alethic Pluralism," Ethical Theory and Moral Practice 20 (2017): 751-761; David Copp, “A Semantic Challenge to Non-Realist Cognitivism," Canadian Journal of Philosophy 48 (2018): 569-591.

${ }^{5}$ For some recent attempts, see Mark van Roojen, "Book Review of On What Matters: Volume Three," Notre Dame Philosophical Reviews (2017), John Skorupski, “On What Matters, Volume Three, by Derek Parfit and Does Anything Really Matter? Essays on Parfit on Objectivity, edited by Peter Singer,” Mind 127 (2018): 602-611; Nicholas Laskowski, "Derek Parfit, On What Matters. Vol. 3; Peter Singer, ed., Does Anything Really Matter? Essays on Parfit on Objectivity," Ethics 128 (2018): 496-505; and Bykvist and Olson, "What Matters in Metaethics".
} 
dialectical situation surrounding NRC, by appeal to truthmaker theory. Second, to develop the above-mentioned cheating intuition into an objection that ultimately reveals a dilemma for the best reading of NRC. Third, to begin bridging the largely unexplored gulf between the metaphysics of normativity and truthmaker theory.

I proceed as follows. In $\ \mathrm{II}$ I introduce Parfit's NRC as he presents it and motivate concern with its plausibility. In $\S I I I, I$, first, introduce truthmaker theory and present the ontological cheating objection. Second, I demonstrate how this objection reveals the most compelling reading of NRC to date, shows how it might block my objection, and clarifies the dialectical situation surrounding NRC. In $§ I V$, I first examine a promising way to argue for NRC. Then, I argue that NRC faces a dilemma and explore whether this dilemma can plausibly be escaped. I conclude, in $\S \mathrm{V}$, with three consequences of the foregoing for the metaphysics of normativity, truthmaking, and their radically underexplored relationship.

Note that my primary concern is with the intelligibility and plausibility of NRC simpliciter. So, this paper is not an exercise in Parfit scholarship but, rather, takes developing the most plausible account of Parfit's NRC as a starting point whilst the object of analysis remains NRC itself. I do think that the form of NRC unearthed below is charitably interpreted as Parfit's own for reasons provided in $\ I I I$, but it is not my aim to demonstrate that here. Let's begin.

\section{Non-Realist Cognitivism?}

Consider,

(A) It is illegal to steal.

(B) It is impolite to eat with your mouth open.

(C) 'Lovee' is a misspelling of 'love' in English. 
(D) Mary's hitting John was morally wrong.

(E) Lucy's being a biochemist is reason to believe that she understands the cell-cycle.

(F) Adam has good reason to take care of his health.

These are first-order normative claims: claims about what an agent has reason or ought to do, think, or feel. They are distinct from purely non-normative claims, such as 'John is injured'.

Parfit claims there are two senses of 'normative': a 'rule-implying' sense and a 'reasonimplying' sense. ${ }^{6}$ Examples of the first are (A)-(C). These, he maintains, all express natural claims, in the sense that their truth is explained in purely natural (e.g. physical or social) terms and is empirically discoverable.

For example, (A) is explained by systems of laws that are created by a community which prohibit certain acts. (B) is explained by widely accepted norms of etiquette in a community and the relevant behaviour violates them. And $(C)$ is explained by certain linguistic rules of a language governing spelling.

(A)-(C) also seem empirically discoverable. One can learn through empirical investigation whether an act violates a law, whether an action contravenes some norm concerning etiquette, or whether a word is spelt incorrectly given the rules of a language.

\footnotetext{
${ }^{6}$ Parfit, On What Matters: Volume Three, 57
} 
Parfit claims (D)-(F) are normative truths in his reason-implying sense and that, in this sense, (D)-(F) express truths that are neither explained in naturalistic terms nor are empirically discoverable.

Take (D), a normative moral claim. Parfit claims the moral wrongness of Mary's hitting of John cannot be fully explained (or reduced to) some purely natural facts, properties, or relations (e.g. the fact that hitting John caused him pain). Nor can there be any empirical evidence regarding (D): whether it was morally wrong for Mary to hit John, Parfit thinks, is not the kind of claim that one can have empirical evidence for or against. Mutatis mutandis for $(\mathrm{E})$, a normative epistemic claim, and (F), a prudential normative claim about (non-moral) reasons for action. $^{7}$

It is regarding normative claims in this reason-implying sense that Parfit's NRC accepts:

(Existence): Normative facts, properties, and relations exist.

(Cognitivism): Normative claims express truth-apt beliefs that purport to describe normative facts, properties, and relations.

(Non-Error-Theory): Some normative claims are true.

(Non-Relativity): True normative claims are true non-relativistically. ${ }^{8}$

(Non-Naturalism): Normative facts, properties, and relations are not fully explained by, reducible to, or identical with natural facts, properties, and relations.

\footnotetext{
${ }^{7}$ Henceforth I use 'normative' only in Parfit's 'reason-implying' sense.

${ }^{8}$ I use 'non-relativistically' to remain neutral on how to formulate the proposed objectivity of normative claims. Candidates include, amongst others, 'stance-independence' (Russ Shafer-Landau, Moral Realism: A Defence [Oxford: Oxford University Press, 2003], 15) and some form of 'agent-' or 'observer-independence' (Enoch, Taking Morality Seriously, 3-4).
} 
So far formulated, this view is indistinguishable from so-called 'robust' or 'metaphysically heavy' Non-Naturalist Normative Realism (NNR). Defended by, amongst others, David Enoch, William FitzPatrick, and Russ Shafer-Landau, NNR also endorses the above claims. ${ }^{9}$

These theorists typically acknowledge that their metaphysical commitments, such as (Existence) and (Non-Naturalism), are prima facie problematic. For example, Enoch grants that there is a 'serious metaphysical worry' for NNR which costs it some 'plausibility points', though he maintains that NNR can successfully defend these commitments. ${ }^{10}$ These worries include familiar queerness, ontological parsimony, and supervenience objections. ${ }^{11}$

Parfit appears to endorse the same metaphysical claims that NNR-ists typically grant raise prima facie worries for their view. But he is adamant that they do not generate any ontological objections. For the crucial difference, Parfit suggests, between NNR (what he calls 'Metaphysical Non-Naturalism') and NRC is that:

Metaphysical Non-Naturalists believe that, when we make irreducibly normative claims, these claims imply that there exist some ontologically weighty non-natural entities or properties. Naturalists find such claims mysterious or incredible. Non-Realist Cognitivists deny that normative claims have any such ontological implications. On this view, normative claims are not made to be true by the way in which they correctly describe, or correspond to, how things are in some part of reality. ${ }^{12}$

\footnotetext{
${ }^{9}$ Enoch, Taking Morality Seriously; Shafer-Landau, Moral Realism: A Defence; William FitzPatrick, "Robust Ethical Realism, Non-Naturalism, and Normativity," in Oxford Studies in Metaethics: Volume 3, ed. Russ Shafer-Landau (Oxford: Oxford University Press, 2008), 159-205. Some other defenders include Michael Huemer, Etbical Intuitionism (New York: Palgrave Macmillan, 2005); Jean E. Hampton, The Authority of Reason (Cambridge: Cambridge University Press, 1998); and Erik J. Wielenberg, Robust Ethics: The Metaphysics and Epistemology of Godless Normative Realism (Oxford: Oxford University Press, 2014).

${ }^{10}$ Enoch, Taking Morality Seriously, 136.

${ }^{11}$ For an excellent overview, see Michael Ridge, "Moral Non-Naturalism," in Stanford Encyclopaedia of Philosophy, ed. Edward N. Zalta (2019).

12 Parfit, On What Matters: Volume Three, 60 (emphasis his).
} 
That is, Parfit's NRC denies whilst NNR accepts:

(Alethic Realism): 'All true claims are made to be true by the way in which these claims correctly describe, or correspond to, how things are in some part of reality. ${ }^{.13}$ (AR)

Parfit seems to think that because NNR accepts (AR), and claims some normative propositions are true, NNR is committed to believing 'some part of reality' makes such claims true. Since NNR accepts (Non-Naturalism), it must admit the existence of irreducibly normative facts, properties, and relations. The positing of these entities is what generates the 'serious metaphysical worry' Enoch acknowledges.

But, Parfit claims, NRC comes with no such ontological commitment, seemingly because it denies (AR). NRC attempts to maintain that true irreducibly normative claims are not made true by anything that exists 'either as natural properties in the spatio-temporal world, or in some non-spatio-temporal realm.' ${ }^{14}$

Parfit claims that logical, mathematical, and necessity claims are also true in this way, provocatively stating:

If we are Non-Realist Cognitivists, we deny that [...] logical and modal claims are made to be true by there being some part of reality which these claims correctly describe, or to which they correspond. If there is any dependence here, this dependence would go the

\footnotetext{
${ }_{13}$ Parfit, On What Matters: Volume Three, 58; also see On What Matters: Volume Two, 746. Denial of (AR) is what is 'non-realist' about NRC.

14 Parfit, On What Matters: Volume Two, 486.
} 
other way. It would be reality that must correspond to these truths. Not even an omnipotent God could have made it false that two plus two equals four. ${ }^{15}$

Instead, Parfit claims normative (and certain other) claims concern phenomena that exist only in a 'non-ontological' sense of 'exist', failing to have any 'ontological status'. ${ }^{16}$ Talk of normative properties, Parfit argues, is merely pleonastic. That is, claims about an action having a normative property adds nothing to the content of a claim made using ordinary predication: ' $x$ has the property of being a reason' adds nothing to the content of the claim that ' $x$ is a reason'.

But if normative property talk is merely pleonastic, then do normative properties themselves exist? If so, is this not just NNR? Parfit's reply is that there just is 'no clear question' whether normative properties exist as part of reality. ${ }^{17}$ Rather, he thinks the only sense of normative properties existing is captured by distinguishing between multiple senses of 'exist', and taking normative properties to exist only in a 'non-ontological' sense.

The reader will rightfully be puzzled by these claims. Before addressing this, I note three good reasons to address NRC's plausibility.

First, if plausible, NRC offers a deeply attractive alternative to traditional non-naturalism by avoiding metaphysical objections that have plagued it and which many take to be decisive. Second, it promises an alternative to Simon Blackburn and Allan Gibbard's Quasi-Realism, which many have rejected due to, inter alia, its non-cognitivism. ${ }^{18}$ And, third, NRC's plausibility

\footnotetext{
15 Parfit, On What Matters: Volume Three, 59

16 Parfit, On What Matters: Volume Two, 487

17 Parfit, On What Matters: Volume Two, 479

18 The relationship between Quasi-Realism and NRC is vexed. Some worry that the latter is just a version of the former (see, e.g., Annika Böddeling, "Cognitivism and Metaphysical Weight: A Dilemma for Relaxed Realism," Australasian Journal of Philosophy (2019): 1-14). Parfit (On What Matters: Volume Three, 63-64) claims that the best version of Quasi-Realism is a version of NRC. I'll assume Quasi-Realism and NRC are distinct, in keeping with the
} 
would radically undermine a strong motivation for naturalism and normative error theories: nonnaturalism's seeming incompatibility with naturalism about reality more generally. If successful, NRC would reveal such a motivation entirely misguided, drastically altering a cornerstone of the meta-ethical landscape.

\section{Truthmaking, Ontological Cheating, and the Real Non-Realist Cognitivism}

\section{A. Truthmaking and Ontological Cheating}

Interpreting NRC is no trivial task. No reading of it in the literature has been widely accepted as even prima facie plausible. This leaves the theory, and how to assess it, deeply unclear. Concerns of unclarity alone, however, are clearly too quick to dismiss NRC.

Behind them, I've suggested, is this intuition: NRC seems like cheating. For how could there be true irreducibly normative propositions that do not incur ontological commitment, that are about entities existing only in some 'non-ontological' sense, and which evade ontological objections?

One might appeal to Parfit's NRC endorsing,

(Plural): There are multiple senses of 'exist' and 'there are/is'. One of these senses is a 'non-ontological' sense.

\footnotetext{
thought that NRC is a novel but unclearly articulated theory, whilst remaining neutral about precisely how to characterise this distinction (doing more would take me beyond the scope of this paper; I plan to explain how my account of NRC suggests an answer to this elsewhere).
} 
(Non-Ontological-Normative): Normative facts, properties, and relations exist only in a 'non-ontological' sense of 'exist'.

Since, if true, it seems trivial that what exists in a 'non-ontological' sense is neither an ontological commitment nor open to ontological objections. But not only is it unclear what this sense of 'exist' amounts to - Parfit nowhere tells us - but even if we charitably grant the intelligibility of this sense of 'exist', why think that normative, mathematical, or any other phenomena exist only in this sense? Nothing in the mere positing of this sense of 'exist' shows this, and that is what NRC needs. ${ }^{19}$

So, the cheating intuition remains. But is it more than just an intuition?

Yes. For one may suspect NRC is guilty of what truthmaker theorists call ontological cheating. To ontologically cheat is to accept some claim as true in one's theory whilst refusing to accept the ontology seemingly necessary to make it true, and, in so doing, illicitly evading ontological objections to one's theory. ${ }^{20}$

To explain: first, distinguish between traditional theories of truth and truthmaker theory. The former address whether truth is a property and, if so, what kind of property. Familiar views here include correspondence, coherence, epistemic, deflationary, and primitivist theories.

Truthmaker theory aims to capture this deeply plausible intuition about the relationship between truth and the world:

\footnotetext{
${ }^{19}$ Mintz-Woo, “On Parfit's Ontology". Also, Jonas Olson, "The Metaphysics of Reasons," in The Oxford Handbook of Reasons and Normativity, ed. Daniel Star (Oxford: Oxford University Press, 2018), 261-265, and Gasser, "Normative Objectivity Without Ontological Commitment" argue that Parfit's (Plural) is unmotivated.

${ }^{20}$ See Fraser MacBride, “Truthmakers," in Stanford Encyclopaedia of Philosophy, ed. Edward N. Zalta (2019): \$3.1 and references therein.
} 
(World-to-Truth): 'Necessarily, truth is not a fundamental feature of reality; what is true depends upon the world. ${ }^{21}$

The thought: what is true metaphysically depends asymmetrically upon the world being some way for it to be true. Take <the rose is red $>.{ }^{22}$ Its truth-value appears anchored to the world such that it cannot vary independently of the world: it is true when the rose is red and false otherwise. And whilst the proposition's truth-value depends upon the world, the world's having a red rose in it does not depend upon the proposition's truth-value. Mutatis mutandis for other truths. $^{23}$

Truthmaker theorists argue that to capture this intuitive dependence, we must admit of truthbearers, truthmakers, and a truthmaking relation. The former are those things that are made true, the latter those that make the former true, and they are related by the truthmaking relation,

(Truthmaking): For all $x, x$ is true iff (and because) there is a $y$ such that $y$ makes $x$ true.

Here 'makes' indicates a non-causal, non-conceptual, asymmetric metaphysical explanation. The thought is not that the rose's being red causes < the rose is red $>$ to be true, nor that it is true because of the concepts rose and red. Rather it is that the rose's being red appears to metaphysically explain that $<$ the rose is red $>$ is true, and not vice-versa. ${ }^{24}$

\footnotetext{
${ }^{21}$ Jamin Asay and Sam Baron, "Deflating Deflationary Truthmaking," Philosophical Quarterly 70 (2020): 6. Alternative motivations for truthmaker theories include appealing to their alleged explanatory resources in either solving some philosophical problem(s) or vindicating certain views; see Adolf Rami, "Introduction: Truth and Truth-Making" in Truth and Truth-Making, eds. E. J. Lowe and Adolf Rami (Stocksfield: Acumen, 2009), 1-36.

${ }^{22}$ I use angled brackets to refer to a proposition: ' $<\mathrm{p}>$ ' means 'the proposition that $\mathrm{p}$ '.

${ }^{23}$ Throughout I use 'the world' and 'reality' as truthmaker theorists do, referring either to a particular entity that exists or a type of entity that exists. In what follows, for a proposition to be 'made true by the world' or 'made true by reality', as I'll now explain, is to have something that exists metaphysically explain the truth of that proposition. ${ }^{24}$ Truthmaker theory is not a complete theory of truth since one can endorse truthmaking without thinking that what it is for something to be true is for it to stand in the truthmaking relation. Truthmaker theories are also not
} 
Truthmaker theorists disagree over, inter alia, a) what truthmakers and truthbearers are, b) what the truthmaking relation is, c) whether some or all truths are made true by things in the world, and d) whether truthmakers necessitate the truth of truthbearers. ${ }^{25}$

We'll take propositions as truthbearers, and allow ordinary particulars, tropes, states of affairs, or properties to be truthmakers. ${ }^{26}$ Next, we'll take the truthmaking relation as a crosscategorical, metaphysical relation that can hold between entities of different kinds which obeys: (Truthmaker): For every $x$ and proposition $<\mathrm{P}>, x$ is a truthmaker of $<\mathrm{P}>$ iff $<\mathrm{P}>$ is true in virtue of $x^{27}$

'In virtue of' can be read either as primitive or as an instance of grounding, a form of asymmetric metaphysical explanation typically elucidated through examples like $<$ the rose is red $>$. Other examples include: < Lucy exists $>$ is grounded in (i.e. metaphysically explained by) the existence of Lucy, or $<$ there is a protest occurring $>$ is grounded in the existence of a group of individuals constituting a protest.

correspondence theories in disguise. As will become clear, the correspondence relation is symmetric and reflexive whilst the truthmaking relation is not (Marian David, "Truth-making and correspondence," in Truth and TruthMaking, eds. E. J. Lowe and Adolf Rami (2009): 146), correspondence is a one-to-one relation whilst truthmaking can have various types of mapping functions, and truthmaking is a dependence relation between a truth and what makes it true whilst correspondence itself is not a dependence relation (Noel Blas Saenz, "An account of truthmaking," Synthese (2020): 3421-3423; also see Matthew Simpson, "Deflationism and Truthmaking," Synthese (2019): 8-10 for discussion). And whilst truthmaking might appear inconsistent with deflationism about truth, this is also contentious (see, again, Simpson, "Deflationism and Truthmaking"), with some even arguing that truthmaking involves commitment to a form of deflationism about truth (see Jamin Asay, A Theory of Truthmaking, [Cambridge: Cambridge University Press, 2020], 105-135). I cannot settle the precise relationship between truthmaking and traditional theories of truth here. Nor do I need to. For I am granting truthmaker theory (minus one common feature of it that, as we'll see, NRC denies) to NRC to make sense of the view. And when the question of its consistency with traditional theories of truth arises in $§ I V$. B., I will charitable assume it consistent with them. If it is not, then, as we'll see there, this is all the worse for NRC.

${ }^{25}$ See Gonzalo Rodriguez-Pereyra, “Truthmakers," Philosophy Compass 1/2 (2006): 186-200; Rami, "Introduction: Truth and Truth-Making"; and MacBride "Truthmaking” for overviews.

26 See Rodriguez-Pereyra, "Truthmakers," 188-190 for a defence.

27 Rodriguez-Pereyra, “Truthmakers," 187 
Finally, as others typically do, we'll also take truthmaker theory to endorse:

(Truthmaker Maximalism): For every proposition $<\mathrm{P}>$, if $<\mathrm{P}>$ is true, then $<\mathrm{P}>$ has a truthmaker.

(Truthmaker Necessitarianism): For every $x$ and proposition $<\mathrm{P}>$, if $x$ is a truthmaker for $<\mathrm{P}>$, then, necessarily, if $x$ exists then $<\mathrm{P}>$ is true. ${ }^{28}$

Call the conjunction of the above standard truthmaker theory.

Now, standard truthmaker theory is often employed to generate ontological cheating objections as follows. ${ }^{29}$ Take,

(Presentism): Only present entities exist.

(Eternalism): Past, present, and future entities exist.

There appear to be true propositions about the past: e.g. <Caesar crossed the Rubicon>. If (Presentism) accepts this then, by standard truthmaker theory, there must be some existents that make those propositions true. But (Presentism) denies the existence of plausible truthmakers for such propositions: past entities. So, the objection goes, by accepting the truth of propositions about the past, without endorsing the existence of the things that seem necessary to make them true, Presentism ontologically cheats.

\footnotetext{
${ }^{28}$ David M. Armstrong, Truth and Truthmakers (Cambridge: Cambridge University Press, 2004), 5

${ }^{29}$ Theodore Sider, Four Dimensionalism (Oxford: Oxford University Press, 2001), 40-41 suggests the 'whole point' of truthmaker theories is to 'catch cheaters'.
} 
Now take $<$ there is a reason to avoid suffering $>$. NRC claims this and other normative propositions state truth-apt claims about, e.g., the irreducibly normative property of being a reason. They add, however, that such claims are true without incurring any ontological commitment, that is, they don't entail there is anything in the world that makes them true. But according to (World-to-Truth) and standard truthmaker theory, there must be something in the world that make such claims true. So, in refusing to accept this, NRC ontologically cheats.

Ontological cheating is a powerful objection. If successful, it shows that NRC is illicitly evading ontological objections by maintaining that irreducibly normative claims are true without anything in the world making them true. Traditional non-naturalists, contrastingly, accept that something must make such claims true, whilst battling to defend introducing irreducibly normative phenomena into our ontology.

\section{B. Real Non-Realist Cognitivism}

We must clarify NRC to establish whether it ontologically cheats. I now argue that the ontological cheating objection reveals the best account of NRC so far presented.

Recall,

(Alethic Realism): 'All true claims are made to be true by the way in which these claims correctly describe, or correspond to, how things are in some part of reality. ${ }^{330}$ (AR)

30 Parfit, On What Matters: Volume Three, 58, 62 
Parfit argues that rejection of (AR) is what distinguishes NRC from traditional nonnaturalism and insulates NRC from common metaphysical objections to the latter. In asking how this could be, some have noted that rejecting (AR) entails rejecting,

(Correspondence): For any proposition $<\mathrm{P}>,<\mathrm{P}>$ is true iff $<\mathrm{P}>$ stands in a correspondence relation to a fact $\mathrm{F}$.

before asking what traditional theory of truth NRC could adopt to justify claiming it evades ontological objections. ${ }^{31}$ But, whilst important, these efforts have failed to provide justification for the claim that true irreducibly normative claims incur no ontological commitment and evade ontological objections.

Failing to engage with truthmaker theory has blinded us to the answer to that question. Once attended to, we can see that rejecting (AR) may involve more than denying (Correspondence). For it can also be read as a rejection of certain tenets of standard truthmaker theory. In particular, as a denial of (World-to-Truth) and (Truthmaker Maximalism) and instead an endorsement of,

(Truth-to-World): There are some truths that do not depend upon the world.

(Truthmaker Anti-Maximalism): There are some propositions $<\mathrm{P}>$ such that it is false that if $<\mathrm{P}>$ is true, then $<\mathrm{P}>$ has a truthmaker.

\footnotetext{
31 This strategy is pursued by Suikkanen, "Non-Realist Cognitivism, Truth, and Objectivity" and Veluwenkamp,
} "Parfit and Scanlon's Non-Metaphysical Moral Realism as Alethic Pluralism". 
Parfit explicitly tells us which truths he takes to demonstrate the above as we saw in $§ I I:$ normative, modal, logical, and mathematical truths. These truths are those that lack truthmakers, that is, on his view, they do not require anything in the world to make them true. ${ }^{32}$

The ontological cheating objection, however, assumes standard truthmaker theory, including (World-to-Truth) and (Truthmaker Maximalism). So, the NRC-ist can argue that they are not ontologically cheating since, whilst they accept a truthmaking relation and that some truths have truthmakers, they deny that normative (and some other) claims require the existence of any entity in the world to make them true. When it comes to such truths, they may claim, there is no way to ontologically cheat. ${ }^{33}$

Is this response even prima facie plausible? Yes, for two reasons. First, in the truthmaking literature, there is fierce debate over (Truthmaker Maximalism)'s plausibility in light of cases where it is unclear either that some truths require truthmakers, or what the truthmakers for some truths could be. ${ }^{34}$

Such cases include negative existential truths ( $<$ Unicorns do not exist $>$ ), modal truths $(<$ it is necessary that $\mathrm{P}>$ ), and truths about the past and future ( $<$ Caesar crossed the Rubicon $>$ ).

\footnotetext{
32 Some, such as Timothy Williamson (in his “Truthmakers and the Converse Barcan Formula," Dialectica 53 [1999] and Modal Logic as Metaphysics [Oxford: Oxford University Press, 2003], 391-403), doubt that there are any 'metaphysically heavyweight' truthmaking principles like those here discussed which posit a metaphysical truthmaking relation that obtains between truthbearers and truthmakers. I cannot respond to this here (though see Asay and Baron 2019 for a response). But I also don't have to. For I'm granting truthmaker theory in this metaphysically committed way to NRC to help make sense of it. If denied, NRC would remain objectionably unclear since, as I now argue and return to in $§ I V$. B., it is in positing such a truthmaking relation whilst denying (Truthmaker Maximalism) that allows for the best articulation of NRC to date.

${ }^{33}$ NRC must mean 'pure' normative propositions, like $<$ lying is wrong $>$, lack truthmakers. For as Copp, "A Semantic Challenge to Non-Realist Cognitivism," 588 notes, some logically complex propositions like <lying is wrong because God says so> obviously have ontological implications. By 'normative propositions' I mean 'pure' ones in what follows.

${ }^{34}$ See David M. Armstrong, Truth and Truthmakers (Cambridge: Cambridge University Press, 2004), 53-67, 83-94; Ross P. Cameron, "How to Be a Truthmaker Maximalist," Noûs 42 (2008): 410-421; Julian Dodd, "Negative Truths and Truthmaker Principles," Synthese 156 (2007): 383-401; and Rodriguez-Pereyra, "Truthmakers", 190-191 for discussion.
} 
NRC's defenders could appeal to these as partners-in-innocence. Insofar as it isn't obvious that these claims fail to falsify (Truthmaker Maximalism), this is a prima facie promising route for NRC.

Second, there is also debate over whether endorsing (Truthmaker Maximalism) is necessary to capture (World-to-Truth). ${ }^{35}$ For notice the latter claim is ambiguous. It has a generic and a non-generic reading:

(Generic): Truth typically depends upon the world; certain paradigmatic truths depend upon the world.

(Non-Generic): All truths depend upon the world. ${ }^{36}$

Even if one accepts that (Truthmaker Maximalism) is required to explain (World-toTruth) on the non-generic reading, one might ask why we should read (World-to-Truth) this way. Perhaps it suffices to capture (World-to-Truth) to read it generically whilst endorsing (Truth-to-World) and (Truthmaker Anti-Maximalism) by appeal to principled exceptions of truthmaker-less truths. The availability of this move is another reason why this response is at least prima facie plausible.

But there is more. For there are some seemingly intractable questions about the details of NRC that this reading - which takes NRC to posit a truthmaking relation, truthbearers, and truthmakers but deny (Truthmaker Maximalism) - clarifies, making a powerful case that it is the best account of the theory available. ${ }^{37}$

\footnotetext{
35 MacBride, “Truthmakers," \$2.1. and references therein.

${ }^{36}$ Rami, "Introduction: Truth and Truth-Making," 7-8.

${ }^{37}$ Veluwenkamp (2017) comes closest to my reading. But, amongst other differences, he misses the role of truthmaking, and conflates features of Parfit's view with those of a different but related position of Tim Scanlon's
} 
First, it clarifies how and why NRC can maintain that normative truths have no ontological implications: their truth requires no truthmakers.

It has appeared puzzling how NRC could claim that there are true irreducibly normative claims whilst denying these incur ontological commitment because we have read into it a Quinean theory of ontological commitment:

(Q-Commitment): A theory, $\mathrm{T}$, is ontologically committed to $x$ iff $x$ lies within the domain of the existential quantifiers of the sentences in T. ${ }^{38}$

Reading NRC as committed to (Q-Commitment) makes it seem obviously confused for Parfit to accept NRC, which quantifies over irreducibly normative phenomena, and then to deny that the theory incurs any ontological commitment to them.

But Parfit nowhere endorses (Q-Commitment). Moreover, his discussion of the senses of 'exist' directly engages with Quine and strongly suggests he actually rejects (Q-Commitment). ${ }^{39}$ To read NRC as having to adopt it is an artefact of the prevalence of (Q-Commitment) and its variants in (meta-)ontology and to assume that there is no plausible alternative. This assumption is false. ${ }^{40}$ Given what rejecting (AR) involves, and Parfit's insistence that NRC lacks ontological commitment, NRC is most charitably understood as endorsing,

\footnotetext{
(in Being Realistic about Reasons [Oxford: Oxford University Press, 2014]. See Michael Ridge, "Relaxing Realism or Deferring Debate?," Journal of Pbilosophy 116 [2019]: 149-173 for an excellent paper on Scanlon's view).

38 This greatly oversimplifies Quine's view but is sufficient here.

39 On What Matters: Volume 2, 475-6; Appendix J

${ }^{40}$ For an excellent overview of alternatives and their plausibility, see Philip Bricker, "Ontological Commitment," in Stanford Encyclopaedia of Pbilosophy, ed. Edward N. Zalta (2016).
} 
(T-Commitment): A theory, $\mathrm{T}$, is ontologically committed to $x$ iff $x$ is something that must exist to make true the propositions expressed in $\mathrm{T}^{41}$

Accepting (T-Commitment), it is clear how and why Parfit thought NRC lacks any ontological commitment to irreducibly normative phenomena: NRC rejects (Truthmaker Maximalism), takes normative claims to be amongst those not made true by the world, and so, by (T-Commitment), avoids ontological commitment to irreducibly normative phenomena.

This reading also explains why Parfit thought traditional non-naturalists did incur commitment to irreducibly normative phenomena. They accept (AR), and so (Truthmaker Maximalism), and are non-naturalists about normativity. So, they must take non-natural entities in the world to make normative claims true, incurring ontological commitment by ( $\mathrm{T}$ Commitment).

Second, Parfit's seemingly mysterious claims that, e.g., normative properties exist only in a 'non-ontological' sense and have 'no ontological status' can be clarified as follows.

On NRC, <there is a reason to avoid suffering > is about, in part, an irreducibly normative property of being a reason. Parfit thinks that this proposition is true whilst not being made true by anything. But he still thinks that the property of being a reason exists in some sense he calls 'non-ontological'. This seems to mean,

(Non-Ontological): $x$ exists in a non-ontological sense iff $x$ is what some true proposition not made true by the world is, at least partly, about.

\footnotetext{
${ }^{41}$ See, e.g., Ross P. Cameron, "Truthmakers and ontological commitment: or how to deal with complex objects and mathematical ontology without getting into trouble," Philosophical Studies 140 (2008): 1-18; “Truthmaking, SecondOrder Quantification, and Ontological Commitment," Analytic Philosophy 60 (2019): 336-360
} 
This makes 'non-ontological' existence just a way of speaking, analogous to Parfit's claim that there is a merely pleonastic sense of 'property'. That seems to clarify the vexed issue of what he could have meant by saying that normative (and certain other) phenomena have no ontological status.

But what is the point of Parfit insisting on the existence of irreducibly normative phenomena in this sense? If 'non-ontological' existence is just some manner of speaking about the subject matter of truthmaker-less propositions, why insist on their existence at all? Left unanswered, one might worry this reveals NRC just a notational variant of an error theory. ${ }^{42}$

In response: negate a claim that something exists in Parfit's 'non-ontological' sense, e.g., $\neg<$ reasons exist in a non-ontological sense $>$. According to (Non-Ontological), this would mean either a) reasons exist in some ontological sense (i.e. they are entities in the world), b) there are no true claims about irreducibly normative reasons, or c) claims about irreducibly normative reasons are not true.

NRC denies a). But it also denies b) and c): NRC maintains there are true normative claims about irreducibly normative reasons (whilst not being made true by anything in the world). ${ }^{43}$ So, Parfit's insistence on the 'existence' of irreducibly normative phenomena in his 'non-ontological' sense is just an insistence upon NRC's commitment to the truth of irreducibly

\footnotetext{
42 Olson, "The Metaphysics of Reasons", 263-264 raises a similar worry in a different way.

43 This is, again, NRC's view about pure normative propositions. For propositions regarding certain natural facts having an irreducibly normative property of being a reason or generating a reason for action, NRC can claim that truths about the normative status of natural facts themselves do not have truthmakers (because their normative status is determined by pure normative truths which themselves lack truthmakers). Suppose we have reason not to hit someone because doing so would be harmful. Why is being harmful a reason not to hit the person? Because an action's hurting someone is a reason not to do it. The proposition <causing harm is a reason not to do something > would then be, on NRC, a truthmaker-less, pure normative proposition.
} 
normative claims despite their lacking truthmakers. Concerns of a disguised error theory too, then, are misguided.

Parfit's 'no clear question' view is also clarified. Recall Parfit thinks there is no clear question whether, e.g., mathematical and normative phenomena exist in an 'ontological' sense. ${ }^{44}$ This sense, he claims, applies only to things that can make propositions true, i.e., entities in the world. But since he thinks that mathematical and normative phenomena can only be understood as the subject matter of some truthmaker-less truths, it is a category mistake to ask of their existence in the world.

A third recalcitrant question: why think NRC faces no ontological objections? Not only because, according to NRC, true normative claims lack ontological commitment to anything, but because of what denying their truth amounts to if they lack truthmakers.

For to deny the truth of a claim that lacks truthmakers is not to deny the existence of something that makes them true, but, rather, to deny that they are true. Compare what Parfit says about mathematical claims, which he thinks lack truthmakers: to deny $<2+2=4>$, he claims, is not to deny whether there are numbers that make this claim true. Rather, it is to deny the proposition is true.

The same is so, he thinks, of true normative propositions. My reading explains this. Since they are true whilst lacking truthmakers, to deny that they are true cannot be to deny the existence of what makes them true but must be to deny that they are true. This immediately clarifies Parfit's claims that one need only engage in first-order theorising to answer whether

44 Parfit, On What Matters: Volume Two, 413, 479-480, 481-487; On What Matters: Volume Three, 60-62, 130-137 227229 
normative claims are true. For the absence of truthmakers for normative propositions means that reflection on the existence and nature of truthmakers cannot play any role in determining whether normative claims are true. ${ }^{45}$

Fourth, Parfit repeatedly states that according to NRC even if there were an empty world (one where nothing existed) it would still be true that $<$ nothing exists $>$, that various claims such as $<2+2=4>$ and $<$ there are reasons to avoid suffering $>$ would be true, and that 'Not even an omnipotent God could have made it false' that $2+2=4{ }^{46}$

Whilst initially perplexing, these remarks are intelligible if we take NRC to be rejecting (Truthmaker Maximalism) and treating normative and mathematical claims as truthmaker-less truths. For, if, e.g., normative propositions are true without being made true by anything that exists in the world, then what exists is irrelevant to their truth-value. This would allow NRC to explain how, even in an empty world, <there are reasons to avoid suffering $>$ is true, since what exists does not affect its truth-value.

Parfit, however, also claims that it is 'reality that must correspond to these [irreducibly normative] truths. ${ }^{47}$ This might suggest that what exists does depend upon, and so is not irrelevant to, normative truths. But recall that 'what exists' is ambiguous on NRC between 'what exists in

\footnotetext{
45 William FitzPatrick, “Ontology for an Uncompromising Ethical Realism,” Topoi 37 (2018): 55 provides an important, plausible alternative reading. Fitzpatrick suggests that Parfit takes normative claims to lack ontological commitment because, Parfit claims, we do not need to settle what exists to settle which first-order normative claims are true. FitzPatrick is effectively suggesting this explains why NRC rejects (Truthmaker Maximalism) and (AR). As my primary aim is not Parfit exegesis, I will not pursue which reading is more faithful to Parfit's text. But I do think we need more to explain why not needing to do ontology to do normative ethics shows that NRC lacks ontological commitment and is not subject to metaphysical or ontological objections. In particular, we need the notion of truthmaking and a truthmaking account of ontological commitment. With these, I am suggesting that it is NRC's truthmaking account of ontological commitment, rejection of (Truthmaker Maximalism), and taking normative truths to lack truthmakers that explains both why true normative claims lack ontological commitment and why one does not need to engage in ontology to ascertain whether normative claims are true. My reading also explains at least Parfit's concern that FitzPatrick identifies amongst so-called 'quietist/relaxed' realists for some form of primacy of first-order theorising over metaphysical theorising in meta-ethics.

${ }^{46}$ See, e.g., Parfit, On What Matters: Volume Three, 59; On What Matters: Volume Two, 485

47 Parfit, On What Matters: Volume Two, 59
} 
the world' ('ontological' existence) and 'what exists merely in the sense of being what a truthmaker less truth is partly about' ('non-ontological' existence). On NRC, what exists in the latter sense does depend upon truthmaker-less truths, whilst what exists in the former does not depend upon any truths. NRC, then, maintains that what exists in the world is irrelevant to the truth of truthmaker-less truths, which is consistent with what 'non-ontologically' exists depending upon normative truths. My reading thus also explains in what sense, on NRC, 'reality' must 'correspond to' or 'depend upon' normative truths.

Fifth, what of NRC's insistence on the non-relativistic truth of true normative propositions? One may suspect that, by denying the existence of non-natural truthmakers for normative propositions, NRC denies itself precisely what other non-naturalists think they need to defend the non-relativistic nature of normative truth.

But read as endorsing truthmaking whilst rejecting (Truthmaker Maximalism) we have an explanation. For suppose normative propositions have truthmakers. The question, then, of whether normative propositions are relativistically-true becomes a question about the nature of these truthmakers: are they the content of agents' beliefs or preferences, or rather something seemingly objective like natural properties (e.g. causing harm) or non-natural properties?

But if normative propositions lack truthmakers, then the question of their relativity cannot be one about the nature of their truthmakers. It is vexing what else NRC could say about what makes normative truths non-relative. But one thing it must say is that their non-relativity is now a first-order normative matter: whether normative propositions are true non-relativistically can only be settled by asking whether such claims are true and why. And to those claiming the objectivity of normative propositions is a metaphysical question, NRC has a principled response: this fails to acknowledge that normative propositions lack truthmakers. 
Sixth, this reading shows how NRC can be motivated in two non-ad-hoc ways. First, whilst it's clear Parfit's regular analogies to mathematical, logical, and modal claims are intended to show how NRC is not ad hoc, it has been unclear why Parfit thought this. After all, it is highly contentious how to understand the metaphysics of mathematics, logic, and modality.

But my reading suggests that the import of these analogies is best explained as providing alleged partners-in-innocence for a principled endorsement of (Truth-to-World) and (Truthmaker Anti-Maximalism). Moreover, it highlights there are other potential partners-in-innocence welldiscussed in the truthmaking literature to motivate such a view.

Second, it suggests another non-ad-hoc motivation: that NRC's claims about the metaphysics of normativity (and other domains) are partly consequences of a more general metametaphysical commitment to standard truthmaker theory minus (Truthmaker Maximalism), accepting (Truth-to-World), (Truthmaker Anti-Maximalism), and (T-Commitment). ${ }^{48}$

Finally, this reading reveals how to assess NRC. Namely, we must assess the plausibility of the notion of truthmaking and account of ontological commitment relied upon to explain the theory, the plausibility of rejecting (Truthmaker Maximalism) and claiming that irreducibly normative propositions are truthmaker-less truths, and what positive argument, if any, can be provided for NRC.

Widespread charges of objectionable unclarity against NRC, then, are unfounded. By ignoring truthmaker theory, we have missed what the rejection of (AR) can be best understood

\footnotetext{
${ }^{48}$ The foregoing suggests Cowie's imposition in “A New Explanatory Challenge for Non-Naturalists" of a 'locality' constraint on a plausible reading of NRC, where NRC must be appealing to something unique about normativity, misunderstands the best version of the theory.
} 
as amounting to, the compelling reading of NRC that emerges, and how to assess the view. And if true, NRC is a deeply attractive theory: revealing that commitment to true irreducibly normative claims plausibly involves no ontological commitment to normative phenomena and faces no ontological and metaphysical objections. This would show such objections entirely confused, and radically undermine a strong motivation for both naturalism and error theory.

I've suggested there is reason to think the above is Parfit's NRC by charitably interpreting his rejection of (AR). If the reader remains unconvinced this is Parfit's theory, then bis NRC remains obscure. But perhaps it really was so: in which case, I submit the reading above as the best version of NRC simpliciter. ${ }^{49}$

It will be important later to remember that NRC as developed here does not reject all of standard truthmaker theory. The account assumes that there is a truthmaking relation, truthmakers, and truthbearers. It only denies (Truthmaker Maximalism) and denies the truthmaking relation obtains between true irreducibly normative propositions and any entities. Rejecting standard truthmaker theory simpliciter - rejecting a substantive truthmaking relation, truthmakers, and truthbearers - would rob NRC of the crucial contrast between propositions that are made true and those that are not, their account of ontological commitment, and my articulation of their commitments by appeal to truthmaker theory.

\footnotetext{
49 Admittedly, Parfit, On What Matters: Volume Three, 61-62 provides an alternative articulation of NRC to what I've developed here. Suggesting that there are two senses of 'reality' and 'real', on one he calls the 'ontologically weighty' sense mere possibilia and abstracta are not part of reality. In that sense, Parfit claims NRC accepts 'the natural world is all of reality' and rejects (AR). But on another 'wide' sense, Parfit claims NRC rejects the claim that the natural world is all of reality and accepts (AR). This is puzzling. First, NRC now looks like severe ontological cheating; a simple refusal to address ontological objections to non-naturalism. Second, it muddies details of NRC such as how normative phenomena are supposed to exist in a 'non-ontological' sense, have 'no ontological status', and how normative claims would be true in an empty world. Finally, any non-question-begging case against accepting that the natural world exhausts reality looks precisely like what traditional non-naturalists offer when acknowledging but resisting the prima facie force of metaphysical objections. For these reasons, and since this paper is not Parfit exegesis, I henceforth bracket this alternative formulation.
} 
I shall now focus upon the positive case for NRC, for three reasons. ${ }^{50}$ First, to avoid this paper becoming solely about (Truthmaker Maximalism). Second, because it has been opaque to date how, even in principle, to argue for NRC. Third, and most importantly, without a positive argument many will think NRC succeeds in trading in the metaphysical mysteries faced by traditional non-naturalism for what looks like a further mystery of how true irreducibly normative propositions could lack truthmakers. ${ }^{51}$ So, I now ask if NRC can show both that (Truthmaker Maximalism) is false and that irreducibly normative truths lack truthmakers.

\section{From Partners-in-Innocence to a Dilemma}

\section{A. Partners-in-Innocence?}

A promising strategy to argue for NRC is to appeal to allegedly truthmaker-less truths as partners-in-innocence. If successful, NRC can argue as follows: some claims of kind K are true and lack truthmakers, such truths are not relevantly disanalogous to normative truths, and so both (Truthmaker Maximalism) is false and normative truths lack truthmakers.

For any candidate partner-in-innocence, we should ask: is it independently plausible that such truths lack truthmakers? And, if so, does the best explanation for why they lack truthmakers show that there is no relevant disanalogy with normative propositions that prevents NRC appealing to them?

\footnotetext{
${ }^{50}$ It would be unhelpful to argue over who faces the burden of proof in this context. Though I suspect many myself excluded - take NRC's radical break from meta-ethical orthodoxy to generate the burden of proof.

51 A complete defence of NRC would involve defence of other tenets of truthmaker theory NRC accepts and of (TCommitment). I grant them here for the sake of argument.
} 
First, consider Parfit's appeal to logical truths like $<$ modus ponens is valid $>$. Such claims, Parfit thinks, lack truthmakers and, hence, any ontological commitment to some logical properties in the world as truthmakers. Even if we charitably assume these claims lack truthmakers, the most plausible explanation for why they might problematises NRC's appeal to them.

Take the property of validity. If one thinks that true claims about an argument's validity lack ontological commitment to anything in the world that makes them true, this seems best explained by the prima facie plausible thought that the property of validity is reducible to something like the relations amongst the contents of the propositions in some argument. ${ }^{52}$

The problem for NRC is that it explicitly denies any such reduction is available for irreducibly normative claims. ${ }^{53}$ This denial is part of why NRC is a form of non-naturalism about the normative, so it cannot surrender this commitment. Moreover, if it did to force this analogy through, then it threatens collapse into reductive naturalism about normativity.

A second candidate partner-in-innocence is analytic truths. Some truthmaker theorists have argued that (Truthmaker Maximalism) should be restricted such that only synthetic truths require truthmakers. ${ }^{54}$ Presumably the force of this thought is that analytic truths are true in virtue of their meaning (where meanings are not reified as entities), whilst synthetic truths seem to make some demand on the world for their truth.

\footnotetext{
52 At least on the account of ontological commitment I've argued NRC is best read as committed to, with which any appeal NRC makes to partners-in-innocence must be consistent with.

53 See FitzPatrick, “Ontology for an Uncompromising Ethical Realism”, 540 for discussion.

54 Rodriguez-Pereyra accepts this view.
} 
The problem here is that, again, even if we grant that analytic truths look like a prima facie plausible candidate to falsify (Truthmaker Maximalism), the reason why they seem so is a feature relevantly disanalogous from normative propositions, at least according to NRC.

This is that analytic truths are analytic, so true in some way due to their meaning. But NRC takes normative propositions to be synthetic. That is, e.g., that $<$ there is a reason to avoid suffering $>$ is not true in virtue of the meaning or content of the words or concepts within it. And, indeed, NRC must say this, since this is partly how they hope to block certain analytic naturalist reductions of normative claims to claims about the natural world.

Third, what of common 'problem cases' for (Truthmaker Maximalism) in the truthmaking literature like negative existentials and claims about the past and future? Again, these are fiercely contested. ${ }^{55}$ But even if they lack truthmakers, there are two important disanalogies between these claims and normative propositions that casts strong doubt on this option.

First, what seems initially appealing about negative existentials and past and future propositions lacking truthmakers is that the former are about things that do not exist, and the latter about what did exist and what will exist. But clearly normative propositions, on NRC, are about neither of these things.

An objection: isn't there $a$ sense in which normative propositions are about things that do not exist, namely, that they are about things that do not exist in the NRC-ist's 'ontological'

${ }^{55}$ See MacBride, “Truthmakers,” $\$ 2$ for discussion. 
sense (i.e. as entities in the world)? Is that not enough to secure an analogy with negative existentials to get a partners-in-innocence appeal through?

No. For negative existentials are about more than what does not exist (in the 'ontological' sense). They are also about some lack or absence of something in the world. That, for example, is what some truthmaker maximalists have appealed to in trying to provide plausible truthmakers for them. ${ }^{56}$ But normative propositions are in no sense about what the world lacks or has an absence of: they are just true normative propositions not made true by the world.

Second, the best explanation truthmaker theorists typically provide for why negative existentials, and claims about the past and future, lack truthmakers involves preserving the thought that they do depend upon the world in a way that the NRC must deny normative propositions do.

To explain: a truth can depend on the world in at least two ways. Take $<$ the rose is red $>$. This proposition, if true, could depend upon the world in the sense that there is some thing in the world (e.g. the particular rose, a trope, the state of affairs that the rose is red, or the property redness instantiated by the rose) that makes it true.

Another way $<$ the rose is red $>$ may depend on the world is not that it depends on some thing in the world but, rather, on how the world is. For example, perhaps it is bow the rose is that is why $<$ the rose is red $>$ true. But, prima facie, how the rose is is not itself an entity. This would suggest there are true propositions dependent for their truth not on what exists but rather on

${ }^{56}$ Rami, "Introduction: Truth and Truth-Making", 15-16 
how the world is. This view hopes to allow for truthmaking without truthmakers, that is, without things that make propositions true by endorsing,

(Truth Supervenes on Being): For every proposition $<\mathrm{P}\rangle$, if $\langle\mathrm{P}\rangle$ is true, then either at least one entity $x$ exists that would not exist if $<\mathrm{P}>$ were false, or at least one entity $x$ does not exist that would exist if $<\mathrm{P}>$ were not true. ${ }^{57}$

Those convinced negative existentials and propositions about the past and future lack truthmakers have typically suggested that, whilst they do not depend on what exists, they do depend on bow the world is: <Unicorns do not exist $>$ and $<$ Caesar crossed the Rubicon $>$ do seem to depend on the world being such that unicorns fail to exist and that past events no longer exist.

NRC, however, cannot appeal to this way of denying (Truthmaker Maximalism) and taking normative propositions to be amongst the truthmaker-less truths. For, as we've seen, NRC is committed to denying that the truth of irreducibly normative propositions depends in any way upon the world, even in the more minimal sense given by (Truth Supervenes on Being). ${ }^{58}$

Perhaps one could try salvaging these partners-in-innocence by claiming that 'exists' in (Truth Supervenes on Being) should be read in Parfit's 'non-ontological' sense as I've explained it such that,

\footnotetext{
${ }^{57}$ See David Lewis, "Truthmaking and Difference-Making," Noûs 35 (2001): 602-615; Julian Dodd, "Is Truth Supervenient on Being?" Proceedings of the Aristotelian Society 102 (2002): 69-86; Jennifer Hornsby, "Truthmaking without Truthmaker Entities," in Truthmakers: the Contemporary Debate, eds. Helen Beebee and Joseph Melia (Oxford: Oxford University Press, 2005), 33-47; Joseph Melia, "Truthmaking without Truthmakers," in Truthmakers: the Contemporary Debate, eds. Helen Beebee and Joseph Melia (Oxford: Oxford University Press, 2005), 67-84. See Rodriguez-Pereyra, "Truthmakers," 190 and references therein for doubts.

58 Remember, NRC means 'pure' normative claims like $<$ there is reason to avoid future agony $>$.
} 
(Truth Supervenes on Being): For every truthmaker-less proposition $<\mathrm{P}\rangle$, if $\langle\mathrm{P}\rangle$ is true, then either at least one other proposition is false that would have been true if $<\mathrm{P}>$ were false, or at least one other proposition is true that would have been false if $<\mathrm{P}>$ were false.

But what proposition would the NRC-ist be appealing to which would be false if $<\mathrm{P}>$ were true, or true if $\langle\mathrm{P}\rangle$ was false? If it is the negation of $\langle\mathrm{P}\rangle$, then this claim is trivial. And it cannot be a proposition about something that exists in the world, since NRC denies truthmakerless propositions depend in any way on the world. So, it must be some other truthmaker-less claim. But that is just to claim that the truth of a truthmaker-less proposition depends, in part, on the truth-value of other truths about the same subject matter and so is trivial and no help here.

Fourth, another common trouble case for (Truthmaker Maximalism), and candidate partner-in-innocence for NRC which Parfit himself mentions, are modal claims. Claims about, e.g., what is necessary seem at least prima facie plausible candidates for truthmaker-less truths. For, as Peter Simons says, they seem to be 'true come (or exist) what may. ${ }^{59}$

Note that the kind of modality is relevant to whether any modal claims constitute a case against (Truthmaker Maximalism). It is contentious what kinds of modality there are. But conceptually and logically necessary truths may plausibly be truthmaker-less. For example, tautologies seem to have their truth settled by the truth-tables of logical constants. Clearly these, however, are not available partners-in-innocence for NRC. ${ }^{60}$

\footnotetext{
${ }^{59}$ Peter Simons, "Negatives, Numbers, and Necessity: Some Worries about Armstrong's Version of Truth-Making," Australasian Journal of Philosophy 83 (2005): 253-261, 254

${ }^{60}$ This is not to deny Cuneo and Shafer-Landau's (“The Moral Fixed Points") view that certain normative (ethical) truths are conceptual truths. Only that it cannot provide NRC a plausible partner-in-innocence since NRC denies that irreducibly normative propositions are conceptual truths.
} 
What of metaphysical and physical modality? This is a vexed question we cannot settle here. Instead, we should ask: if they are truthmaker-less, can NRC plausibly claim they are relevantly analogous to true normative propositions to constitute a partner-in-innocence?

The prospects of this move are much better than any we've discussed. For NRC maintains true irreducibly, normative propositions are necessarily true. This is charitably read, I suggest, as the claim that such propositions are metaphysically necessary. If so, and if normative propositions are necessarily true, then the NRC-ist can subsume true normative propositions under all metaphysically necessarily true propositions, which are true whilst lacking truthmakers. ${ }^{61}$

An objection: suppose < there is an even prime number $>$ is metaphysically necessary. This, and many other, metaphysically necessary claims are about the existence and nature of entities. But normative claims are about what there is reason to do, one ought to do, or should be the case. Is this not a salient disanalogy?

This is a disanalogy. But NRC can plausibly respond that it is not a relevant one. For, they may claim, Simons' explanation of why metaphysical necessity claims are truthmaker-less is one that also applies to true, pure normative propositions: they are true or false regardless of what exists or what the world is like. ${ }^{62}$

This partners-in-innocence move does require NRC to take true normative propositions to be metaphysically necessary. But notice that this is a widely-held assumption by almost every

\footnotetext{
${ }^{61}$ Parfit, On What Matters: Volume Two, 479 appears to suggest Parfit himself may have intended this. ${ }^{62}$ This would also explain why Parfit takes mathematical propositions to lack truthmakers: they are, he claims, metaphysically necessary.
} 
everyone in meta-ethics. So insofar as the success of this move depends on this assumption, it is one that, at least prima facie, NRC's opponents likely share.

\section{B. A Dilemma}

But there is a problem. For there is good reason to think that the rejection of (Truthmaker Maximalism), whilst still allowing for the idea that some truths have truthmakers, is an unstable position. And, given the dialectical situation NRC is in here, this worry is particularly troubling for them.

As Ross Cameron and Julian Dodd have argued, if we take the idea of truthmaking seriously, and yet we also allow exceptions to (Truthmaker Maximalism), then it is unclear why this should not motivate a wholesale rejection of truthmaking altogether. ${ }^{63}$

For what could possibly justify a restriction of those truths that have truthmakers without also motivating rejecting truthmaking itself? Moreover, one may suspect, as we'll see, that the very motivation behind admitting of truthmaking is that (World-to-Truth) captures an intuition about truth and not just the asymmetric dependence of some truths on what exists.

If restricting (Truthmaker Maximalism) cannot avoid this worry, then NRC as developed here is troubled. For it faces a dilemma. It would have to either accept (Truthmaker Maximalism) or it reject truthmaking altogether.

${ }^{63}$ Cameron, "How to Be a Truthmaker Maximalist," 411-413; Dodd, "Negative Truths and Truthmaker Principles," 393-395 
The first horn would be lethal: NRC cannot accept (Truthmaker Maximalism). If it does, then it accepts that for any proposition, there is some entity in the world that makes it true. But, first, NRC refuses to admit of the existence of any such entities for normative propositions. So, it would be ontologically cheating. And, second and decisively, NRC explicitly denies (Truthmaker Maximalism), since it holds that there are some truths that lack truthmakers by endorsing (Truthmaker Anti-Maximalism). So, accepting (Truthmaker Maximalism) would render NRC internally inconsistent.

The second horn would be, if not fatal, a serious blow. My rational reconstruction of NRC by appeal to truthmaker theory has allowed us to clarify the theory, explain why Parfit would have ever thought it had the purported advantages he suggested, and respond to every common objection to it. This rational reconstruction takes NRC to be rejecting (Truthmaker Maximalism).

But it also depends upon NRC accepting the rest of standard truthmaker theory, maintaining that there is a substantive truthmaking relation that can obtain between truthbearers and truthmakers. So, if NRC's rejection of (Truthmaker Maximalism) involved a denial that there was a substantive truthmaking relation, truthmakers, and truthbearers, then the view cannot be rationally reconstructed in the form I've offered here.

For, first, notice that it does not suffice to clarify the commitments of NRC to note only that it rejects (Truthmaker Maximalism). This is because one can reject (Truthmaker Maximalism) because ones denies that there is a truthmaking relation, and not because one thinks 
there is this truthmaking relation but that there are certain truthbearers (e.g. normative propositions) that lack truthmakers. ${ }^{64}$

Second, in rejecting truthmaking, NRC would lose the contrast between those truths that are made true (e.g. empirical propositions) and those that are not (normative, mathematical, logical, and modal), and their truthmaking account of ontological commitment. But, as I argued, these claims are necessary to avail of my explanations of NRC's core commitments and alleged avoidance of ontological and metaphysical objections to non-naturalism. Since this reconstruction appears to be the best articulation of the view available, this would be a devastating blow to NRC..$^{65}$

So, can one deny (Truthmaker Maximalism) without also motivating the rejection of truthmaking tout court? In particular, can NRC do so?

A first attempt: (World-to-Truth) is ambiguous, that is, the claim that truth depends upon the world has both a generic and non-generic reading. Those who motivate (Truthmaker Maximalism) by appeal to the former claim seem to require reading it as non-generic, i.e., about all truths depending on the world.

${ }^{64}$ The former is how and why, for example, Williamson in "Truthmakers and the Converse Barcan Formula,"; Modal Logic as Metaphysics, 391-403 rejects (Truthmaker Maximalism). The thought is that (Truthmaker Maximalism) may be false because it assumes that there is a metaphysical truthmaking relation that takes truths and entities as relata, and not because no claims are true or because their truth is metaphysically inexplicable.

${ }^{65} \mathrm{My}$ claim is not that NRC becomes literally unintelligible if it eschews standard truthmaker theory's truthmaking relation. Rather, it is that NRC cannot be reconstructed as I have done so here if it rejects that notion of truthmaking, and since this reconstruction provides the best account of NRC available this would be a serious blow to it. If NRC adopted some deflationary view of the truthmaking relation, then NRC cannot be the view I've developed as my reconstruction depends upon a substantive understanding of the truthmaking relation which itself provides a substantive contrast between those truthbearers that, when true, stand in that relation and those that do not. 
NRC could exploit this ambiguity and insist that (World-to-Truth) be read as about certain paradigmatic truths, and that taking only some propositions (e.g., those about the natural world) to be made true suffices to explain this. But defenders of (Truthmaker Maximalism) motivated by capturing (World-to-Truth) can plausibly respond as follows.

What motivates the non-generic reading of the intuition is that taking any truth to depend upon the world seems to be an intuition about truth, and not any particular truths. That is, that whatever truth is it seems in virtue of its nature to be something that depends upon the world. If so, this attempt to deny (Truthmaker Maximalism) being required to best explain (World-toTruth) fails, and with it this attempt to restrict the class of truthmaker-possessing truths without demotivating truthmaking altogether.

Does the seemingly plausible partner-in-innocence of metaphysically necessary propositions not allow NRC a principled rejection of (Truthmaker Maximalism) that does not motivate rejection of truthmaking altogether?

This is unclear at best. First, it does not do so if the best way to capture (World-toTruth) is to endorse (Truthmaker Maximalism). Nor will it if the intuition behind the former claim is one about truth, such that, necessarily, truths are such that they depend upon what exists in the world.

Second, whilst taking normative propositions, such as pure moral principles, to be metaphysically necessary is a common assumption in meta-ethics, it is much more controversial than many assume. Not only is there an absence of an argument for it, but as Kit Fine, Anandi Hattiangadi, and Gideon Rosen have argued, there is reason to think some motivations for the 
view (such as thinking the normative strongly supervenes on the non-normative with metaphysical necessity) are misguided. ${ }^{66}$

I cannot settle these issues here. But the relevant point for us is this: subsuming normative propositions into the class of metaphysically necessary propositions, to run this response, relies upon the falsity of recent strong doubts over the metaphysical necessity of normative propositions. This is a further worry for this response.

Third, even if the above two worries are misguided, further details are needed about precisely why metaphysical necessity claims being true 'come what may' makes it plausible that they lack truthmakers. Such reasons, however, are scarce in the truthmaking literature itself. I've only suggested that if this claim can be unpacked to justify a restriction on (Truthmaker Maximalism), then NRC can appeal to it as a partner-in-innocence to justify claiming true normative propositions lack truthmakers. But much more needs to be said for this slogan to actually justify such a restriction, and to show that in doing so it does not demotivate truthmaking tout court.

Finally, perhaps NRC can adopt some theory of truth that would justify rejecting (Truthmaker Maximalism) without casting doubt upon the idea of a truthmaking relation. Such a theory might try to explain, by appeal to what truth is, why some truths have truthmakers whilst others do not.

${ }^{66}$ Kit Fine, "The Varieties of Necessity," in Modality and Tense: Philosophical Papers (Oxford: Oxford University Press, 2005), 235-261; Anandi Hattiangadi, "Moral Supervenience,." Canadian Journal of Philosophy 48 (3-4) (2018): 592-615; Gideon Rosen, "What is Normative Necessity?" in Metaphysics, Meaning, and Modality: Themes from Kit Fine (Oxford: Oxford University Press, Forthcoming). 
Such a theory would have to adopt truth pluralism, the view that there are at least two truth properties. If not, then appeal to what truth is alone would not explain why some truths have truthmakers and others do not. This is because what it would amount to for something to be true would be the same for any proposition: but if so, how could appeal to a theory of truth explain why some truths have truthmakers and others do not?

Adopting truth pluralism, NRC could argue as follows. Perhaps the correspondence theory of truth is true of those propositions concerning the natural world, whilst some other theory of truth is correct for propositions about, e.g., abstract objects, possibilia, and/or normative propositions. This, one may think, would allow an explanation of why the former are made true by something in the world, whilst the latter are not.

Truth pluralism is deeply contentious ${ }^{67}$ But even if we granted truth pluralism, we must ask what theory of truth NRC could consistently adopt to achieve this rejection of (Truthmaker Maximalism). Jussi Suikkanen has, however, argued that coherentist, pragmatist, epistemic, and deflationist theories are available to NRC as accounts of normative truth, forcing primitivism onto NRC. ${ }^{68}$

I'll now suggest, pace Suikkanen, that NRC can adopt a form of truth pluralism that accepts deflationism for normative truths, that this is the most promising way to escape my dilemma, and end by noting some doubts over its success.

Coherentism and pragmatism are unavailable, Suikkanen argues, since they entail firstorder relativism about normative propositions by respectively making them true relative to either

\footnotetext{
${ }^{67}$ See Douglas Edwards, The Metaphysics of Truth (Oxford: Oxford University Press, 2018) for a defence. 68 Suikkanen, "Non-Realist Cognitivism, Truth, and Objectivity", 199-202. Mintz-Woo, "On Parfit's Ontology", also addresses Suikkanen's arguments, and argues against thinking NRC's adopting truth pluralism would vindicate it.
} 
being a member of a maximally coherent set of beliefs or being instrumentally valuable. Epistemic theories are unavailable as they posit an epistemic normative notion, such as superassertibility, to explain what truth is which forces a trilemma on NRC. The trilemma is seen by asking how NRC can explain the aforementioned normative notion. Suikkanen argues it reveals three fatal options: appealing to some other meta-ethical theory (rendering it unable to capture epistemic normativity and facing whatever objections it takes that other theory to face), appealing to another theory of truth (which, Suikkanen argues, is not an option), or provides another epistemic account of the normative notion in question (generating an infinite regress).

Granting Suikkanen's case against deflationism momentarily, this would leave primitivism about truth, the view that a proposition's truth consists in in it possessing some unanalysable property of truth. And the fatal problem for our purposes is that if NRC must endorse primitivism about truth for normative propositions, then it has no answer as to why, if such claims lack truthmakers, this does not demotivate talk of truthmaking altogether - since this theory is silent on anything about the nature of the truth property enjoyed by true normative propositions.

Now, Suikkanen argues that if NRC accepted deflationism, we can ask if it accepts deflationism or inflationism about facts. Accepting the former might seem to render NRC indistinguishable from NNR. To see why, recall that NRC insists that NNR should be rejected because it posits worldly normative facts as truthmakers for normative propositions, denying that 'it is a fact that suffering is bad' is just another way to state 'suffering is bad'. But if all facts are understood deflationarily, then this insistence by NRC becomes very hard to understand. For such a rejection of NNR presupposes an inflationary, ontologically committal notion of facthood. Deflationism about facts, however, eliminates the distinction between ontologically and nonontologically committing notions of facts, making all facts non-ontologically committing 
restatements of the contents of true propositions. If NRC accepted deflationism about facts, this crucial contrast between notions of facts is lost, leaving NRC unable to articulate the above distinction between NRC and NNR.

Additionally, NRC cannot distinguish itself from NNR by insisting that the former denies but the latter accepts that these deflated normative facts are truthmakers for normative propositions. For recall that truthmakers are supposed to be entities the admittance of which is an ontological commitment (this is partly why NRC wants to avoid them). Deflationism about facts entails that all facts are non-ontologically committing ways of describing reality and so are ineligible to be truthmakers. Since deflationism about facts eliminates facts as candidate truthmakers by making all facts non-ontologically committing ways of describing reality, NNR and NRC cannot be distinguished by appeal to competing truthmaking claims involving deflated facts. ${ }^{69}$

To distinguish itself from NNR, Suikkanen suggests that NRC could instead accept inflationism about facts whilst maintaining that there are no such inflationary normative facts. This, Suikkanen claims, seem to make NRC a form of normative error theory. For whilst deflationism allows NRC to predicate truth to normative propositions, if fact inflationism is true and NRC denies there are inflationary normative facts, then it denies there are any normative facts - and that is an error theory. So, deflationism about truth appears unavailable to NRC.

\footnotetext{
${ }^{69}$ The fact that NNR accepts correspondence for normative truths and NRC does not won't suffice to enable NRC to distinguish itself from NNR. Because if it did, then it would allow NRC to claim that normative truths lack truthmakers whilst claiming that NNR accepts that they do. And on deflationism about facts, NRC cannot make sense of that claim. For deflationary normative facts are ineligible to be truthmakers (they are not worldly entities that could make normative propositions true but just restatements of the content of true propositions). So, commitment to deflationism about all facts would collapse the distinction it draws between NRC and NNR.
} 
There is, however, a way out of Suikkanen's dilemma. This is by, first, recognising that we are granting NRC truth pluralism whilst Suikkanen's dilemma assumes truth monism. Second, NRC could adopt pluralism about facts. On this view, NRC accepts correspondence for truths that are made true, deflationism for those that are not, and that there are two notions of a fact: an inflationary, ontologically committing notion that concerns worldly entities that can serve as candidate truth-makers and a deflationary, non-ontologically committing notion concerning mere restatements of the content of true propositions.

With truth and fact pluralism, NRC can articulate the distinction between it and NNR whilst also avoiding becoming an error theory. For if there are both inflationary and deflationary notions of facthood, the distinction between ontologically and non-ontologically committing facts - collapsed by monist deflationism about facts - is saved. NRC can then claim that NNR is the view that normative facts are inflationary facts that serve as truth-makers of normative truths, whereas NRC denies that there are such inflationary normative facts (so no normative truthmakers) and that there are only deflationary normative facts. This avoids NRC becoming an error theory too, since, assuming fact pluralism, not all facts are inflationary and so accepting only deflationary normative facts avoids being a denial that there are any normative facts.

If plausible, this form of NRC would escape my dilemma. But it faces three challenges. First, why think that deflationism about truth entails that a given truth lacks a truthmaker? Deflationism entails that truth is exhausted by something like: $<\mathrm{P}>$ is true iff $\mathrm{P}$. But why should that entail that $<\mathrm{P}>$ cannot be made true? Appeal to correspondence being correct for other truths is no help: correspondence may be a sufficient condition for being made true, but why assume it is necessary? This is especially difficult assuming - as we are in NRC's favour - that 
deflationism and truthmaker theory are compatible. Absent an answer, deflationism about truth may fail to justify thinking normative truths lack truthmakers at all. ${ }^{70}$

Second, even if being deflationarily-true entails that a given truth lacks a truthmaker, why should we think that normative truths are candidates for truth only in the deflationary sense? On monist theories of truth, such a question is easily answered: all truths are true in the only sense of truth. But pluralist theories must explain why certain truths are candidates for truth in only one sense of truth. If NRC cannot do this, then appeal to truth pluralism will not justify a relevant restriction since normative truths might be candidates for truth in, e.g., the correspondence (and thus truthmaking) sense.

Third, can NRC justify adopting these brands of truth and fact pluralism in the first place? This is unclear at best; both are highly controversial, and their defence is no trivial task. If NRC's only justification for adopting them is to avoid metaphysical objections to non-naturalism and my dilemma, then NRC may do so at the cost of a different kind of ontological cheating: ad hoc moves to avoid pressing objections.

These concerns provide reason to doubt NRC will succeed in showing that these pluralisms justify rejecting (Truthmaker Maximalism) without demotivating truthmaking simpliciter, or in motivating such pluralism at all. I cannot settle whether they are fatal here. I can, however, conclude that NRC must show that such concerns are misguided. For if it cannot, then either it avoids my dilemma only to face further troubling objections, or it is impaled upon the dilemma of accepting (Truthmaker Maximalism) or rejecting truthmaking simpliciter. The former

\footnotetext{
${ }^{70}$ Deflationary normative facts would be ineligible to be truthmakers. Does that not show, assuming deflationism for normative truths, that normative propositions can be deflationarily-true whilst lacking truthmakers? No. For we might instead think that if normative propositions all lack truthmakers, then they are all false because they lack truthmakers, instead of thinking normative propositions can be deflationarily-true without truthmakers. NRC thus requires an argument to establish the latter.
} 
horn would leave NRC both guilty of ontological cheating and internally inconsistent, whilst the latter would rob NRC of the clarity, and explanation of its alleged strengths, that truthmaker theory provided - plunging it back into unclarity's abyss.

\section{Conclusion}

I have provided the clearest and most compelling account of NRC to date, clarified the otherwise-opaque dialectic between NRC and its opponents, and provided a novel ontological cheating objection to NRC. Consideration of that objection resulted in an argument that casts doubt upon NRC's ability to reject (Truthmaker Maximalism) without demotivating truthmaking simpliciter. Appealing to truth and fact pluralism to justify restricting (Truthmaker Maximalism) does provide a promising way out of my dilemma for NRC. But I've argued the final success of this move remains to be seen. An important concern for future work on NRC, then, should be to explore this and other responses to my dilemma that hope to show how one could justify claiming normative truths lack truthmakers without demotivating truthmaking altogether.

I conclude with three positive consequences of the foregoing for the metaphysics of normativity, truthmaking, and their radically underexplored relationship.

First, as this discussion of NRC makes clear, truthmaker theory has gone almost completely ignored in contemporary meta-ethics and, more generally, in metaphysics of normativity. ${ }^{71}$ Curiously, normative claims have also been largely ignored in the truthmaking literature itself.

\footnotetext{
${ }^{71}$ Exceptions include Jamin Asay, "Truthmaking, Metaethics, and Creeping Minimalism," Philosophical Studies 163 (2013): 213-232; T. Ryan Byerly, "Moral Property Eliminativism,” Philosophical Studies 175 (2018): 2695-2713.
} 
Attention to truthmaking may generate interesting novel views like NRC, provide new ways to attempt to further meta-normative debate, and enrich the truthmaking literature itself. Given the sophisticated development of truthmaker theory in metaphysics, even if there are those sceptical of truthmaking in meta-ethics, it would be an important addition to metanormative theorising for these doubts and their implications to be explored in this context.

Second, and more generally, inattentiveness to meta-metaphysical questions - such as whether there is a truthmaking relation, and whether to accept truthmaking-based accounts of notions such as ontological commitment - can render us blind to novel views in first-order metaphysics. This is what I have suggested has occurred in the case of NRC. In doing so, I've highlighted strong reason to rectify the general lack of meta-metaphysical reflection within normative metaphysics. It is curious, for example, that many meta-ethicists seem to assume a Quinean theory of ontological commitment without comment. Given the objections it faces and the sophisticated development of alternatives in meta-ontology, this should give us pause and motivate reflection on how this and other unargued meta-metaphysical assumptions have shaped meta-ethical debate. Amongst other things, being sensitive to how meta-metaphysical issues interact with first-order metaphysical questions about normativity can help us better understand how we could answer the latter in tangible ways, as my account of NRC demonstrates.

Third, if truthmaking is plausible, there are interesting and deeply neglected questions to address regarding truthmaking in meta-ethics. Two highlighted here are these. If (Truthmaker Maximalism) is true, then: what are the truthmakers for normative propositions? Jamin Asay suggests that meta-ethicists have been making implicit truthmaking claims without realising it; one might read, e.g., naturalists and non-naturalists as offering competing truthmakers for 
normative propositions. ${ }^{72}$ But even if so, given our best accounts of truthmaking, are these plausible claims about truthmaking? And, if (Truthmaker Maximalism) is false, and its falsity does not demotivate truthmaking altogether, then with NRC we should ask: do true normative propositions lack truthmakers?

\section{Acknowledgements}

I am exceptionally grateful to my doctoral supervisors, Roger Crisp and Tim Williamson, for their immensely helpful feedback, criticism, time and encouragement. I am extremely grateful to Ralf Bader, Christopher Cowie, Hartry Field, Geoff Keeling, Matthew Kramer, Mary Leng, TienChun Lo, Dan Marshall, Lucy Mellor, Andreas Mogensen, Theron Pummer, Gonzalo Rodriguez-Pereyra, Richard Rowland, Justin Snedegar, Daniel Stoljar, Bart Streumer, Mark Warren, an audience at the National Taiwan University, and audiences at my lectures on metaethics at the University of Oxford for their very helpful feedback on or discussion regarding this paper or related topics. I am similarly grateful to William Fitzpatrick, two anonymous referees for this journal, and two associate editors for their very helpful feedback which greatly improved the paper. This work has been supported at various times by an Arts and Humanities Research Council Studentship, a Graduate Development Scholarship from St Anne's College, Oxford, and an Aristotelian Society Bursary.

72 Asay, "Truthmaking, Metaethics, and Creeping Minimalism," 221-222. He goes further, arguing that truthmaking provides a resolution to the infamous problem of creeping minimalism. 